\title{
Karyotype composition of some rodents and marsupials from Chapada Diamantina (Bahia, Brasil)
}

\author{
Pereira, $L G .{ }^{\text {a* }}$ and Geise, $L .{ }^{\mathrm{b} *}$

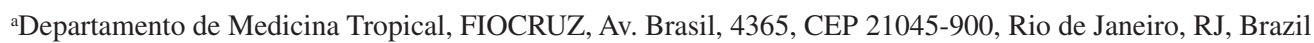 \\ bLaboratório de Mastozoologia, Departamento de Zoologia, Instituto de Biologia, \\ Universidade do Estado do Rio de Janeiro - UFRJ, \\ Rua São Francisco Xavier 524, CEP 20559-900, Rio de Janeiro, RJ, Brazil \\ *e-mail: luciana@gpereira.bio.br, lenageise@gmail.com
}

Received May 25, 2005 - Accepted December 16, 2005 - Distributed August 31, 2007

(With 2 figures)

\begin{abstract}
The Chapada Diamantina (CD) is located in Bahia State, between $11-14^{\circ} \mathrm{S}$ and $41-43^{\circ} \mathrm{W}$, being part of the Serra do Espinhaço. The occurrence of different habitats and transition areas permits an interesting mammal fauna composition, with species from different biomes living in sympatry. Species of Didelphimorphia and Rodentia are important members of mammal communities in almost all different habitats, and morphological and cytogenetic characters are important for a correct identification of most of these species. In this work 258 specimens of small mammals from the orders Didelphimorphia (six genera and six species) and Rodentia (two families, five Sigmodontinae tribes, nine genera and 11 species) were collected during the whole field work (44 nights with traps). Chromosome preparations were obtained from 145 specimens from the species: Marmosops incanus, Gracilinanus microtarsus, Monodelphis domestica, Akodon aff. cursor, Necromys lasiurus, Cerradomys sp., Oligoryzomys fornesi, O. nigripes, O. rupestris, Calomys expulsus, Rhipidomys macrurus, Wiedomys pyrrhorhinus and Thrichomys inermis. Didelphis albiventris, Micoureus demerarae, Thylamys karymii and Nectomys sp. were identified by morphological characters. Most analyzed specimens do not show karyotype variation. However, numerical chromosomic variation was found in two individuals of Akodon aff. cursor $(2 \mathrm{n}=15)$ and in one individual of Cerradomys sp. $(2 \mathrm{n}=51)$. Structural variation in karyotype was observed in seven individuals of Cerradomys sp., showing one additional pair of metacentric chromosomes.
\end{abstract}

Keywords: Rodentia, Didelphimorphia, mammal taxonomy, cytogenetics, chromosome variation.

\section{Composição cariotípica em alguns roedores e marsupiais da Chapada Diamantina (Bahia, Brasil)}

\begin{abstract}
Resumo
A Chapada Diamantina (CD) está localizada no estado da Bahia entre as coordenadas $11^{\circ}-14^{\circ} \mathrm{S}$ e $41^{\circ}-43^{\circ} \mathrm{W}$, fazendo parte da Serra do Espinhaço. A ocorrência de diferentes hábitats e áreas de transição levam a uma composição da mastofauna interessante, podendo ser encontradas espécies de diferentes biomas convivendo em simpatria. As espécies das ordens Didelphimorphia e Rodentia compreendem membros importantes nas comunidades de mamíferos, praticamente em todos os diferentes habitats, e as características morfológicas e citogenéticas são importantes para a correta identificação da maioria das espécies. Neste trabalho, 258 espécimes de pequenos mamíferos das ordens Didelphimorphia (seis gêneros e seis espécies) e Rodentia (duas famílias, cinco tribos Sigmodontinae, nove gêneros e onze espécies) foram coletados durante todo o trabalho de campo (44 noites de armadilhamento). As preparações cromossômicas foram obtidas em 145 indivíduos dentre as seguintes espécies: Marmosops incanus, Gracilinanus microtarsus, Monodelphis domestica, Akodon aff. cursor, Necromys lasiurus, Cerradomys sp., Oligoryzomys fornesi, O. nigripes, O. rupestris, Calomys expulsus, Rhipidomys macrurus, Wiedomys pyrrhorhinus e Thrichomys inermis. Didelphis albiventris, Micoureus demerarae, Thylamys karymii e Nectomys sp. foram identificadas por análises morfológicas. A maioria dos indivíduos coletados não apresentou variação cariotípica. Porém, variação cromossômica numérica foi encontrada em dois espécimes de Akodon aff. cursor $(2 \mathrm{n}=15)$ e em um indivíduo de Cerradomys sp. $(2 \mathrm{n}=51)$. Foi também observada variação estrutural no cariótipo de sete indivíduos de Cerradomys sp., mostrando um par a mais de cromossomos metacêntricos.
\end{abstract}

Palavras-chave: Rodentia, Didelphimorphia, taxonomia de mamíferos, citogenética, variação cromossômica. 


\section{Introduction}

Small mammals (volant and non-volant) represent $80 \%$ of all mammal richness from Brazil (Fonseca et al., 1996). Didelphimorphia and Rodentia comprehend species living almost in all different habitats in the Neotropical region, from Pliocene and Paleocene periods (respectively) to the present (Anderson, 1967; Vaughan, 1978). Morphological and cytogenetic characters are important for proper identification of most species, and the analysis of karyotypes is essential for cryptic species (Bonvicino and Geise, 1995; Geise, 1995 and Geise et al., 1998). Cytogenetic analyses can also show the diversity existing in each chromosome complement and corroborate studies of geographic variation among populations. Marsupials normally do not present variation in their autosomal chromosomes, classified in the patterns of 14, 18 or 22 chromosomes (Paresque et al., 2004; Reig et al., 1977; Souza et al., 1990; YonenagaYassuda et al., 1982). On the other hand, Neotropical rodents (Cricetidae, Sigmodontinae in particular) present chromosomal variation within and among populations, species and genera (e.g. Baker et al., 1983; Bianchi et al., 1983; Geise, 1995; Geise et al., 1998; Patton and Sherwood, 1983; Reig, 1989). The association between chromosomal variation and species diversity in rodents means that karyological diversity is related to the differentiation of populations and constitutes an adaptative component in the phyletic evolution (Corti and Rohlf, 2001; Patton and Sherwood, 1983).

Chapada Diamantina (CD) is located at Bahia State, between $11-14^{\circ} \mathrm{S}$ and $41-43^{\circ} \mathrm{W}$ being part of the Serra do Espinhaço. This formation was formed during the Medium Pre-Cambrian and is constituted of a series of mountains with a "Y" form. Altitude varies from $300 \mathrm{~m}$ to $2,033 \mathrm{~m}$, most of the formation being located between $800 \mathrm{~m}$ and 1,200 $\mathrm{m}$. The total area of the Chapada Diamantina, including the Chapada Diamantina National Park, is approximately $38,000 \mathrm{~km}^{2}$, and is $300 \mathrm{~km}$ from the Atlantic Ocean (Parrini et al., 1999).

A great diversity of habitats can be found within the Chapada Diamantina, with waterlogged areas (Marimbus), vegetational physiognomies of the Cerrado domain (Oliveira-Filho and Ratter, 2002) dry and wet forests and dry open vegetation, as well as transition areas among them. This diversity characterizes a transition area among three biomes - Atlantic Forest, Caatinga and Cerrado (Brazão and Araújo, 1981; Parrini et al., 1999), although being considerated as Dry Forest from the Northeast, according to Dinnerstein et al. (1995). Such heterogeneity is also influenced by a mass of humid air from the ocean that is blocked by the mountain relief, making the east Chapada wet and the west Chapada dry.

The occurrence of these transition areas and habitat diversity permits an interesting mammal fauna composition, with species from different biomes living in sympatry. Therefore, a correct evaluation of mammal diversity can lead us to a better comprehension of the evolutionary history of taxa, geographic variation pat- terns and a better delimitation of their geographic ranges. Here we report on the karyotype composition of some non-volant small mammals species (marsupials and rodents) trapped in several specific localities of the Chapada Diamantina.

\section{Materials and Methods}

\subsection{Field work}

Four mammal trapping expeditions were carried out in the Chapada Diamantina from 2002 to 2005 in different vegetational types. Traps were set differently according to the development of the research, topography and presence of trees (arboreal traps set up to $3 \mathrm{~m}$ ), mostly placed ca. 15 to $20 \mathrm{~m}$ apart one from another in transect lines. Two live trap models were used (Sherman and Tomahawk) with banana/manioc/peanut butter/bacon as bait in all expeditions, and pit fall systems twice (in the first and second expeditions). Trap lines were kept open during two to 17 consecutive nights, with a total of 12,947 traps/nights effort.

For each specimen collected, karyotype was prepared in the field, tissue (liver) samples were collected and fixed in $96 \%$ ethanol, ectoparasites were collected, and skins, skulls and partial skeletons were prepared for future deposit in the Museu Nacional (MN) and Museu de Zoologia da USP (MZUSP) mammal collections. Standard external measurements in millimeters and weight in grams were recorded. Habitat data, coordinates and altitude were obtained at each capture line. Habitat classification follows Eiten $(1972,1994)$ and OliveiraFilho and Ratter (2002).

Rodent specimens were identified to species level by karyological analysis and by comparison with voucher specimens deposited in museums. Morphological characters (skin and skull) were considered for species identification in comparison to previous descriptions for Didelphimorphia (Emmons and Feer, 1997; Lange and Jablonski, 1998; Mustrangi and Patton, 1997) and Rodentia (Emmons and Feer, 1997; Geise, 1995; Gonçalves et al., 2005; Langguth and Bonvicino 2002; Tribe, 1996; Weksler, 1996). Specific names followed Wilson and Reeder (2005), when a more recent account was not available.

\subsection{Chromosome preparation}

Chromosome in metaphases were obtained with in vitro culture (culture of bone marrow grown in Dulbecco's MEM with $10 \%$ fetal bovine serum and colchicine), or in vivo preparation, with injection of colchicine $(0.1 \%)$ to stop the cell division in the metaphase (Ford and Hamerton, 1956). Conventional coloration with Giemsa 5\% were used to observe diploid (2n) and autosomal (NA, excluding sexual chromosomes) numbers and chromosome morphology variation. This analysis was carried out using an optic photomicroscope (Hund Wetzlar - H500 LL HP100), and karyotypes were set and compared with the literature. 


\section{Results and Discution}

A total of 258 specimens of small mammals from the orders Didelphimorphia (six genera and six species) and Rodentia (two families, five Sigmodontinae tribes, nine genus and 11 species) were collected during the whole field work. Chromosome preparations were obtained from 145 specimens (Appendix and Table 1).

Most analyzed specimens do not show karyotypes with variation (Table 1). However, three specimens presented numerical chromosomic variation, two individuals of Akodon aff. cursor $(2 \mathrm{n}=15)$ and one individual of Cerradomys sp. $(2 \mathrm{n}=51)$. Only the genus Akodon presents a historical of chromosome variation among and between populations (Fagundes et al., 1998; Geise, 1995; Geise et al., 1998). Structural variation in karyotype was observed in seven individuals of Cerradomys sp., showing an additional pair of metacentric chromosomes. Species of marsupials analyzed show two of the three karyotypes recognized for this family $(2 n=14$ and $2 \mathrm{n}=18$ ). The karyologic form $2 \mathrm{n}=22$ occurs in Didelphis albiventris (Yonenaga-Yassuda et al., 1982), a species collected by us but not cytogenetically analyzed.

\section{Order Didelphimorphia Family Didelphidae}

\section{Marmosops incanus (Lund, 1840)}

Vegetation types where specimens were found: Floresta Estacional Decidual and Cerrado sensu stricto.

Cytogenetic analysis: Three specimens were karyotyped (1 female and 2 males), showing a diploid number of 14 and NA of 24. Pairs 1 to 4 are submetacentric (the first three are large and the fourth is a medium size), pairs 5 and 6 are small meta/submetacentrics. The $\mathrm{X}$ chromosome is a medium/small metacentric and the Y chromosome is the only acrocentric. This karyotype pattern is the same found in other specimens from different habitats (Paresque et al., 2004, Rens et al., 2001; Svartman and Vianna-Morgante, 1998).

\section{Gracilinanus microtarsus (Wagner, 1842)}

Vegetation types where specimens were found: Floresta Estacional Decidual and Cerradão.

Cytogenetic analysis: One female was karyotyped showing $2 \mathrm{n}=14$ and $\mathrm{NA}=20$. Autosomal complement comprises three pairs are large submetacentric (pairs 1,2 and 3), the pair 4 is metacentric medium and pairs 5 and 6 are small acrocentric. The $\mathrm{X}$ chromosome is a smaller acrocentric in the karyotype and the $\mathrm{Y}$ chromosome also is a small acrocentric. This karyotype is similar to those described at the first for G. microtarsus (Carvalho et al., 2002) and to specimens from Espírito Santo (Paresque et al., 2004). We collected two specimens and karyotyped only one (LG409). The morphological comparison with the species description of the genus did not allowed a conclusive identification, as both specimens show characters in accordance to G. microtarsus and G. agilis (Costa et al., 2003). As karyotype information is not conclusive for Didelphimorphia species identification, those specimens need a more detailed morphological analysis.

\section{Monodelphis domestica (Wagner, 1842)}

Vegetation types where specimens were found: Floresta Estacional Decidual, Cerrado sensu stricto and Campo Rupestre.

Table 1. Results of analyzed karyotypes. \# Individuals = number of individuals; $2 \mathrm{n}=$ diploid number; and NA = number of autosome arms.

\begin{tabular}{|c|c|c|c|c|}
\hline Order & Species & \# Individuals & $2 n$ & NF \\
\hline \multirow[t]{3}{*}{ Didelphimorphia } & Marmosops incanus & 3 & 14 & 24 \\
\hline & Gracilinanus microtarsus & 1 & 14 & 20 \\
\hline & Monodelphis domestica & 2 & 18 & 22 \\
\hline \multirow[t]{13}{*}{ Rodentia } & Akodon aff. cursor & 2 & 15 & 26 \\
\hline & & 20 & 16 & 26 \\
\hline & Necromys lasiurus & 12 & 34 & 34 \\
\hline & Cerradomys sp. & 58 & 50 & 64 \\
\hline & & 7 & 50 & 66 \\
\hline & & 1 & 51 & 65 \\
\hline & Oligoryzomys fornesi & 5 & 62 & 64 \\
\hline & Oligoryzomys nigripes & 3 & 62 & 80 \\
\hline & Oligoryzomys rupestris & 2 & 46 & 52 \\
\hline & Calomys expulsus & 6 & 66 & 68 \\
\hline & Rhipidomys macrurus & 1 & 44 & 48 \\
\hline & Wiedomys pyrrhorhinus & 1 & 62 & 86 \\
\hline & Thrichomys inermis & 21 & 26 & 48 \\
\hline
\end{tabular}


Cytogenetic analysis: Two specimens were karyotyped (one male and one female) showing $2 \mathrm{n}=18$ and $\mathrm{NA}=22$. The autosomal complements comprise three pairs of biarmed chromosomes (pairs 1,2 and 6) and five acrocentric pairs. The $\mathrm{X}$ chromosome is a small acrocentric and the $\mathrm{Y}$ chromosome is a little smaller than the $\mathrm{X}$ chromosome. This pattern is similar to that described by Rens et al. (2001) and different to the one described by Paresque et al. (2004), caused by differences in chromosomal nomenclature.

\section{Order Rodentia}

\section{Family Cricetidae}

\section{Akodon aff. cursor}

Vegetation types where specimens were found: Floresta Estacional Decidual and Cerrado sensu stricto.

Cytogenetic analysis: Following Rieger et al. (1995), $A$. aff. cursor is assigned to specimens with $2 n=16$, collected in northeastern Brazil, forming, together with $A$. cursor and A. montensis (Thomas, 1913) three monophyletic clades that match their respective chromosomal characteristics (Geise et al., 2001). Twenty-two individuals were karyotyped (13 females and 9 males), with almost $2 \mathrm{n}=15 / 16$ and NA $=26$. The chromosomal complement comprises six biarmed pairs (pairs 1 to 5 and 7) from large to very small in size and one medium acrocentric (pair 6). The $\mathrm{X}$ chromosome is a small acrocentric and the $\mathrm{Y}$ is a smaller metacentric. This karyotype is similar to the one described by Maia and Langguth (1981), that was the first described karyotype of Akodon with 16 chromosomes. In our sample, two females from different localities and habitats lost a chromosome, probably one corresponding to $\mathrm{X}$ (Figure 1), a pattern already described for the genus and species (Bianchi and Contreras, 1967; Fagundes et al., 1998). Chromosomal variation (numerical and structural, both in autosomal and sexual chromosomes) is very common in the Akodon species, having been increased by the maintenance of several polymorphic chromosome rearrangements

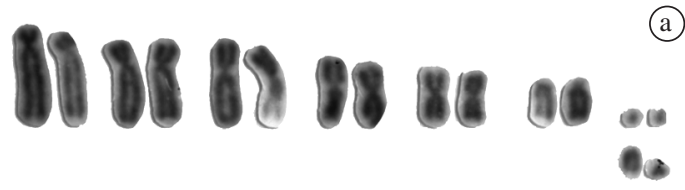

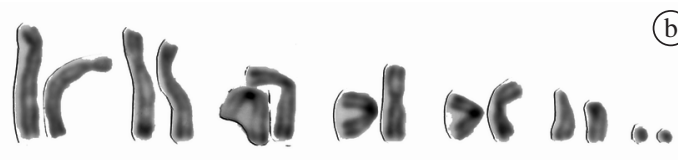

Figure 1. Conventional Giemsa staining karyotype of Akodon aff. cursor. a) Complete karyotype, without any variation (CD 30); and b) Karyotype with chromosome variation in their diploid number $(2 \mathrm{n}=15, \mathrm{NA}=26)$, one $\mathrm{X}$ chromosome is missing (CD102).
(Bianchi et al., 1983; Fagundes et al., 1998; Geise, 1995; Geise et al., 1998; Maia and Langguth, 1981; Silva and Yonenaga-Yassuda, 1998).

For a better identification of sexual chromosomes and the absence of one $\mathrm{X}$ chromosome, $\mathrm{C}$ banding techniques were attempted with no interpretable results. In both female specimens where one sexual chromosome was absent (Figure 1), the one that was present was identified by morphological comparison with all the samples here analysed.

\section{Necromys lasiurus (Lund, 1841)}

Vegetation types where specimens were found: Floresta Estacional Decidual, Cerrado sensu stricto and Campo Rupestre.

Cytogenetic analysis: Four females and eight males were karyotyped. All studied specimens were karyotypically similar $(2 \mathrm{n}=34$ and NA $=34)$, comprising 15 acrocentric pairs (large to small) and one small metacentric pair (pair 16). The $\mathrm{X}$ chromosome is a medium acrocentric and the $\mathrm{Y}$ is a small acrocentric, only perfectly identified by G-banding technique. This pattern is similar to the one previously most commonly described karyotypes (Fagundes and Yonenaga-Yassuda, 1998; Geise, 1995; Kasahara and Yonenaga-Yassuda, 1983; Yonenaga, 1975). The karyotype of $N$. lasiurus is mostly constant for diploid and number of autosome armss, but variation in diploid number can occur (Fagundes and Yonenaga-Yassuda, 1998; Maia and Langguth, 1981 and Svartman and Almeida, 1993b) due to a heterozygous Robertsonian rearrangement or simple centric fusion, resulting in $2 \mathrm{n}=33$.

\section{Oligoryzomys fornesi (Massoia, 1973)}

Vegetation types where specimens were found: Floresta Estacional Decidual.

Cytogenetic analysis: This species was formerly considered as synonymous to $O$. microtis (Olds and Anderson, 1987), but was recently considered a valid species, based on morphological and karyological studies (Bonvicino and Weksler, 1998). Four males were karyotyped $(2 \mathrm{n}=62$ and NA $=64)$, and the autosomal complement comprises two biarmed pairs (one medium and one small) and 28 acrocentic pairs. This result is similar to that previously described for $O$. fornesi (Weksler and Bonvicino, 2005).

\section{Oligoryzomys nigripes (Olfers, 1818)}

Vegetation types where specimens were found: Floresta Estacional Decidual.

Cytogenetic analysis: Two female and one male were karyotyped, showing $2 \mathrm{n}=62$ and $\mathrm{NA}=82$. The chromosomal complement comprises 11 biarmed pairs and 19 acrocentric ones and the $\mathrm{X}$ chromosome is a large submetacentric and the $\mathrm{Y}$ is the smallest acrocentric. This result is similar to that described for this species 
(Yonenaga et al., 1976). Oligoryzomys nigripes normally presents variation in their number of autosome arms (NA) due to pericentric inversions occurring in pairs 3, 4 and 8, showed in individuals from Bahia, Rio de Janeiro, São Paulo, Minas Gerais, Espírito Santo and Rio Grande do Sul (Almeida and Yonenaga-Yassuda, 1991; Andrades-Miranda et al., 2001; Bonvicino and Weksler, 1998; Bonvicino et al., 2001; Paresque et al., 2004; Yonenaga et al., 1976; Zanchin, 1988). The X and Y chromosomes can also be polymorphic (Almeida and Yonenaga-Yassuda, 1991; Andrades-Miranda et al., 2001, Bonvicino et al., 2001; Paresque et al., 2004).

\section{Oligoryzomys rupestris}

(Weksler and Bonvicino, 2005)

Vegetation types where specimens were found: Floresta Estacional Decidual and Campo Rupestre.

Cytogenetic analysis: This Oligoryzomys species present the lowest diploid number for this genus (Weksler and Bonvicino, 2005). Two males were karyotyped showing a $2 n=46$ and $N A=52$. The autosomal complement comprises four biarmed pairs (two large and two small) and 18 acrocentric pairs (one large and 17 small). This karyotype is also similar to one previously described by Silva and Yonenaga-Yassuda (1997) for specimens collected in Pico das Almas (Bahia State).

\section{Cerradomys sp.}

Vegetation types where specimens were found: Floresta Estacional Decidual, Mata de Galeria, Cerrado sensu stricto, Cerradão e Campo Rupestre.

Cytogenetic analysis: "Oryzomys subflavus" was known as one species from all of the Cerrado and Caatinga. Recently, different species were described among specimens previously identified as $O$. subflavus, through morphologic analysis, studies with DNA sequences and chromosomal data (Andrades-Miranda et al., 2002; Bonvicino et al., 1999; Bonvicino and Moreira, 2001; Langguth and Bonvicino, 2002). All these species present different karyotypes, which may be derived from one another by a small number of chromosome arrangements (Bonvicino et al., 1999). Recently Weksler et al. (2006) reviewed the genus Oryzomys, and concluded that these species belong to another genus (Cerradomys). The cytotype analyzed here shows a $2 \mathrm{n}=50$ and NA $=64$, an undescribed species distributed in Bahia and Minas Gerais States. We analyzed 66 individuals (36 females and 30 males) with a karyotype normally comprising eight biarmed pairs (five larges and three small) and 16 acrocentric pairs (two large and 15 small). The $\mathrm{X}$ chromosome is a medium acrocentric and the $\mathrm{Y}$ is a small one. Seven individuals present nine pairs of submeta/metacentric chromosomes, changing the number of autosome arms up to 66 (Figure 2). One specimen shows $2 \mathrm{n}=51$, with one large acrocentric chromosome without homologous and one more pair of small acrocentric chromosomes. Such differences
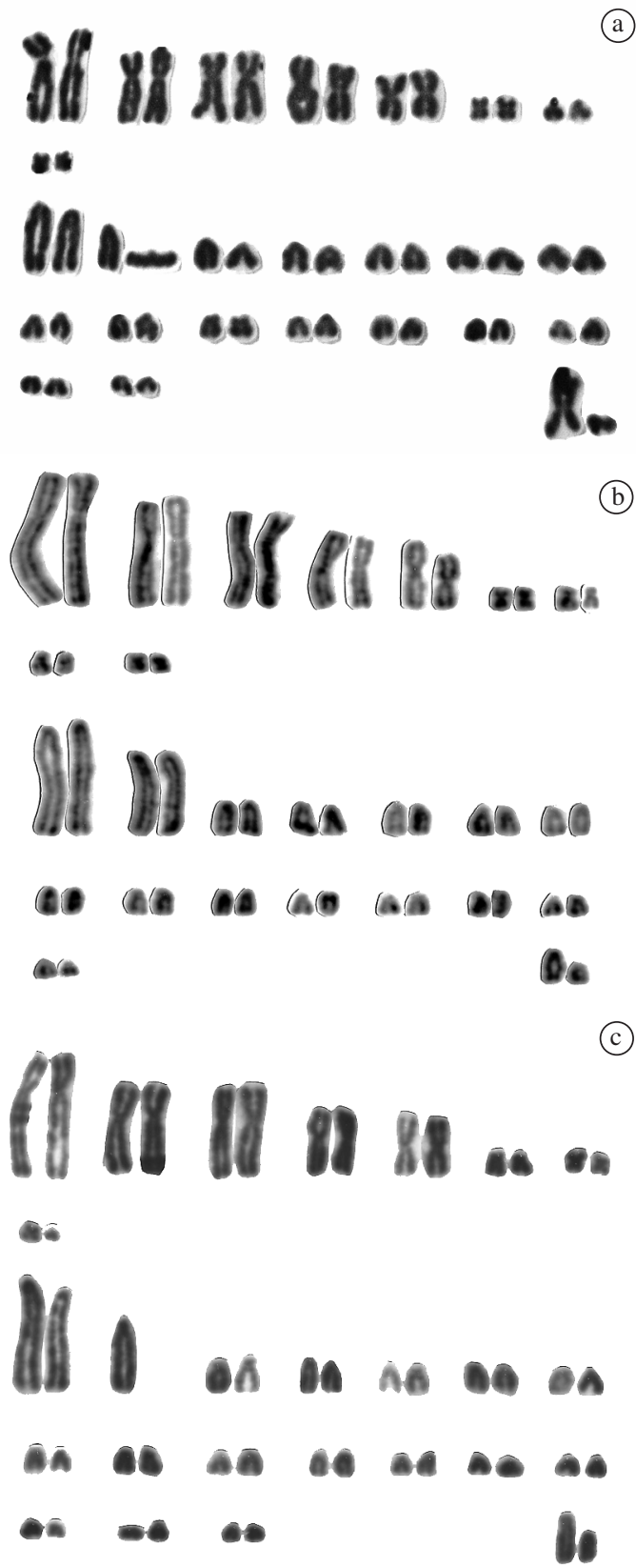

Figure 2. Conventional Giemsa staining karyotype of Cerradomys sp. a) Karyotype recognized to this species (LG 403); b) with chromosome variation in their number of autosome arms (2n = 50, NA = 66) (CD029); and c) Specimen (CD200) with variation in their diploid number, one missing chromosome in pair 10 and one more pair of small acrocentric chromosomes $(2 \mathrm{n}=51, \mathrm{NA}=65)$.

could be explained by the fission of one large chromosome, resulting in one pair of acrocentric chromosomes, but unfortunately banding techniques used by us do not show elucidative metaphases to prove this hypothesis. The individuals with $2 \mathrm{n}=51$ were found in the population (Figure 2) among individuals without numerical variation in their karyotypes. Another variation in the 
karyotype of this individual was the morphology of the $\mathrm{X}$ chromosome (medium metacentric). Variation in the $\mathrm{X}$ chromosome was previously described for species from Venezuela (Aguilera et al., 1995) and for species from Cerradomys (Svartman and Almeida, 1992a; Languth and Bonvicino, 2002).

\section{Calomys expulsus (Lund, 1841)}

Vegetation types where specimens were found: Mata de Galeria, Cerrado and Campo Rupestre.

Cytogenetic analysis: Karyologic analyses of six specimens ( 5 males and 1 female) showed $2 \mathrm{n}=66$, $\mathrm{NA}=68$, a chromosome complement similar to that described for this species (Bonvicino and Almeida, 2000; Bonvicino et al., 2003; Svartman and Almeida, 1992b). The autosome complement comprised two pairs of biarmed chromosomes (one large and one medium) and 30 acrocentric pairs varying gradually in size. The $\mathrm{X}$ chromosome is a large submetacentric and the $\mathrm{Y}$ chromosome is a medium sized acrocentric or submetacentric.

\section{Wiedomys pyrrhorhinus (Wied-Neuwied, 1821)}

Vegetation types where specimens were found: Campo Rupestre.

Cytogenetic analysis: Only one male was trapped and karyotyped. Conventional analyses of chromosomes confirmed the diploid number of 62 and NA of 86 already reported (by Maia and Langguth, 1987). The autosomal complement consists of 13 pairs of biarmed chromosomes and 17 pairs of acrocentric chromosomes, varying from medium to small. The $\mathrm{X}$ chromosome corresponds to the largest acrocentric autosome in size and the $\mathrm{Y}$ is a small one. Gonçalves et al. (2005) studied the genus Wiedomys with morphological, chromosomic and molecular data and described another species (W. cerradensis (Gonçalves et al., 2005)). They identified differences in chromosomal complement $(2 \mathrm{n}=60$ and NA $=88)$ and morphological characters (presence of alisphenoid strut). The individual here analyzed presented chromosome complement similar to W. pyrrorhinus, but presented also the alisphenoid strut (W. cerradensis). This already happened in two individuals (one from Caruaru and other from Santana de Ipanema) (Gonçalves et al., 2005), in this case as well as here, the identification of these specimens is based on cytogenetic data.

\section{Rhipidomys macrurus (Gervais, 1855)}

Vegetation types where specimens were found: Floresta Estacional Decidual.

Cytogenetic analysis: Even though our sampling effort included 838 traps/night in trees, only one specimen was trapped during all the field work, and the karyotype shows a $2 n=44$ and NA $=48$. The autosomal complement comprises 18 pairs of acrocentric chromosome decreasing in size from large to small, and three small met- acentric pairs. $\mathrm{X}$ and $\mathrm{Y}$ chromosomes are acrocentric, the first is medium sized and the other is small. These diploid and autosomal numbers are also related to $R$. latimanus (Gardner and Patton, 1976) and R. leucodactylus (Zanchin et al., 1992). Svartman and Almeida (1993a) and Corrêa and Pessôa, (1996) described a similar karyotype for Rhipidomys sp. from the Distrito Federal, São Paulo and Minas Gerais states. The taxonomic review of this genus made by Tribe (1996), analyzing morphological characters concluded that specimens from the Distrito Federal and Minas Gerais (with different NA 48, 49 and 51) correspond to the species Rhipidomys macrurus. Specimens from São Paulo also with the same $2 \mathrm{~N}$ and a NA $=49$ were related by Tribe (1996) to Rhipidomys cf. macrurus (undescribed species). Silva and YonenagaYassuda (1999), in a compilation study about autosomal and sexual chromosomes of Rhipidomys did not relate any karyotype to R. macrurus, despite Tribe's (1996) revision. Since the specimen analyzed here was collected in the Chapada Diamantina, we can conclude, also based on the morphological comparison, that $R$. macrurus is the most probable occurring species of this geographic region, increasing the geographic distribution to the east. According to Souza (2005) and Silva and YonenagaYassuda (1999), Rhipidomys mastacalis (Lund, 1840) and Rhipidomys sp. species were also registered in the Chapada Diamantina.

\section{Family Echimyidae}

\section{Thrichomys inermis (Pictet, 1841)}

Vegetation types where specimens were found: Floresta Estacional Decidual, Mata de Galeria, Cerrado sensu stricto and Campo Rupestre.

Cytogenetic analysis: Thrichomys was recognized as a monospecific genus for a long time, but recently Braggio and Bonvicino (2004) concluded that it includes at least four species, based on analyses of molecular and karyotypic data and geographic distribution. Thrichomys inermis occurs in Bahia State and its distribution is coincident with the $2 \mathrm{n}=26$ population (Bonvicino et al., 2002). Nine males and 12 females were karyotyped, showing a $2 \mathrm{n}=26$ and $\mathrm{NA}=48$. The autosomal complement presents two large metacentric pairs (the second one with a large interstitial secondary constriction in the short arm, which is the NOR), one large submetacentric pair and nine metacentric or submetacentric pairs that gradually decrease in size. The $\mathrm{X}$ chromosome is a large acrocentric and the $\mathrm{Y}$ is a small metacentric. The autosomal pattern found here is similar to that described earlier (Bonvicino et al., 2002; Leal-Mesquita et al., 1993).

\section{Final Considerations}

Among the 13 species here analysed, only $6.9 \%$ show a different karyotype from those previously described. We found species described as typical from the Atlantic for- 
est, such as Marmosops incanus (Fonseca et al., 1996) and Oligoryzomys rupestris from the Cerrado (Weksler and Bonvicino, 2005). O. rupestris was previously collected in open areas, and our specimens were collected in forested areas (Floresta Estacional Semidecidual from Itaetê).

Some species were only found in one region of the Chapada Diamantina, such as Wiedomys pyrrorhinus, Oligoryzomys rupestris, O. fornesi and Rhipidomys macrurus, showing a geographic differentiation among all sampled habitats. Beside such geographic characterization, we could also observe that two of the most common species in our sample, Thrichomys inermis and Cerradomys sp. are widespread species, occurring in 80 and $100 \%$ of the sampled areas respectively.

As is usual in small mammal inventories, some species are common, in opposition to those that are rare or trap shy (L. Geise, personal observation). Our trapping effort showed a similar pattern, such difference in trapped specimen leading to a different interpretation of karyological results. Akodon aff. cursor and Cerradomys sp. showed karyological differences in relation to what can be found in the literature, as they correspond to the most common species. A more extensive trapping effort is necessary to establish a more detailed population structure based on chromosome differentiation or similarity and the recognition of possible new species.

Such results show that a long term capture effort is necessary to establish a real geographic and genetic scenario of this important small mammal species assemblage, as species commonly related to the Caatinga, Cerrado and Atlantic Forest were registered in this restrict geographic area.

Acknowledgments - We thank the Head of the PARNACD, I.L.M. de Almeida, for local support and Dr. M. de Vivo (BIOTA/FAPESP) for support in the first fieldwork. This work was supported by PRONEX/CNPq (Dra. L. Geise and Dr. H. Seuánez) and CNPq (Process n ${ }^{\circ}$ 473447/2003-7). LGP received a graduate fellowship from CAPES and LG from CNPq and UERJ (Prociência).

\section{References}

AGUILERA, M., PÉREZ-ZAPATA, A. and MARTINO, A., 1995. Cytogenetics and karyosystematics of Oryzomys albigularis (Rodentia, Cricetidae) from Venezuela. Cytogenetics and Cell Genetics, vol. 69, p. 44-49.

ALMEIDA, EJC. de and YONENAGA-YASSUDA, Y., 1991. Pericentric inversions and sex chromosome heteromorphisms in Oryzomys nigripes (Rodentia, Cricetidae). Caryologia, vol. 44, no. 1 , p. 63-73.

ANDERSON, S., 1967. Introduction in the rodents, p. 206-209. In ANDERSON, S. and JONES, Jr., JK. Recent mammals of the world. A synopsis of families. The Roland Press Company, New York.

ANDRADES-MIRANDA, J., OLIVEIRA, LFB., LIMA-ROSA, CAV., NUNES, AP., ZANCHIN, NIT. and MATTEVI, MS., 2001. Chromosome studies of seven species of Oligoryzomys (Rodentia: Sigmodontinae) from Brazil. Journal of Mammalogy, vol. 82, no. 4, p. 1080-1091.
ANDRADES-MIRANDA, J., ZANCHIN, NIT., OLIVEIRA, LFB., LANGGUTH, AR. and MATTEVI, MS., 2002. (T2AG3)n telomeric sequence hybridization indicating centric fusion rearrangements in the karyotype of the rodent Oryzomys subflavus. Genetica, vol. 114, p. 11-16.

BAKER, RJ., KOOP, BF. and HAIDUK, MW., 1983. Resolving systematic relationship with G-Bands a study of five genera of South American cricetine rodents. Systematic Zoology, vol. 32, no. 4, p. 403-416.

BIANCHI, NO. and CONTRERAS, JR., 1967. The chromosomes of the field mouse Akodon azarae (Cricetidae, Rodentia) with special reference to sex chromosome anomalies. Cytogenetics, vol. 6, p. 306-313.

BIANCHI, NO., REDI, C., GARAGNA, C., CAPANNA, E. and MANFREDI-ROMANINI, MG., 1983. Evolution of the genome size in Akodon (Rodentia, Cricetidae). Journal of Molecular Evolution, vol. 19, p. 362-370.

BONVICINO, C. and ALMEIDA, FC., 2000. Karyotype, morphology and taxonomic status of Calomys expulsus (Rodentia: Sigmodontinae). Mammalia, vol. 64, no. 3, p. 339-351.

BONVICINO, CR., D'ANDREA, PS. and BORODIN, PM., 2001. Pericentric inversion in natural populations of Oligoryzomys nigripes (Rodentia: Sigmodontinae). Genome, vol. 44, p. 1-6.

BONVICINO, CR. and GEISE, L., 1995. Taxonomic status of Delomys dorsalis collinus Thomas, 1917 (Rodentia, Cricetidae) and description of a new karyotype. Zeitschrift fur Säugetierkunde, vol. 60, p. 124-127.

BONVICINO, CR., LIMA, JFS. and ALMEIDA, FC., 2003. A new species of Calomys Waterhouse (Rodentia, Sigmodontinae) from the Cerrado of Central Brazil. Revista Brasileira de Zoologia, vol. 20, no. 2, p. 301-307.

BONVICINO, CR. and MOREIRA, MAM., 2001. Molecular phylogeny of the genus Oryzomys (Rodentia: Sigmodontinae) based on cytochrome b DNA sequences. Molecular Phylogenetics and Evolution, vol. 18, no. 2, p. 282-292.

BONVICINO, CR., OTAZU, IB. and BORODIN, PM., 1999. Chromosome variation in Oryzomys subflavus species group (Sigmodontinae, Rodentia) and its taxonomic implication. Cytologia, vol. 64, p. 327-332.

BONVICINO, CR., OTAZU, IB. and D'ANDREA, PS., 2002. Karyologic evidence of diversification of the genus Thrichomys (Rodentia, Echimyidae). Cytogenetic and Genome Research, vol. 97 , p. 200-204.

BONVICINO, CR. and WEKSLER, M., 1998. A new species of Oligoryzomys (Rodentia, Sigmodontinae) from northeastern and central Brazil. Zeitschrift fur Säugetierkunde, vol. 63, p. 90-103.

BRAGGIO, E. and BONVICINO, CR., 2004. Molecular divergence in the genus Thrichomys (Rodentia, Echimyidae). Journal of mammalogy, vol. 85, no. 2, p. 316-320.

BRAZÃO, JE. M. and ARAÚJO, AP., 1981. In Projeto RadamBrasil, folha SD. 24 Salvador: geologia, geomorfologia, pedologia, vegetação e uso potencial da terra. p. 405-464. Ministério das Minas e Energia, Rio de Janeiro, Brasil, 624p.

CARVALHO, BA., OLIVEIRA, LFB., NUNES, AP. and MATTEVI, MS., 2002. Karyotypes of nineteen marsupial species from Brazil. Journal of Mammalogy, vol. 83, no. 1, p. 58-70. 
CORRÊA, MMO. and PESSÔA, LM., 1996. O cariótipo de Rhipidomys sp. (Rodentia: Cricetidae) do norte de Minas Gerais. Resumos do XXI Congresso Brasileiro de Zoologia, Porto Alegre, resumo n 1061 , p. 226.

CORTI, M. and ROHLF, FJ., 2001. Chromosomal speciation and phenotypic evolution in the house mouse. Biological Journal of the Linnean Society, vol. 73, p. 99-112.

COSTA LP., LEITE YLR., AND PATTON JL., 2003. Phylogeography and systematic notes on two species of gracile mouse opossums, genus Gracilinanus (Marsupialia: Didelphidae) from Brazil. Proceedings of the Biological Society of Washington, vol. 116, p. 275-292.

DINERSTEIN, E., OSLON, DM., GRAHAN, DJ., WEBSTER, AL., PRIMM, SA., BOOKBINDER, MP. and LEDEC, G., 1995. A Conservation Assessment of the Terrestrial Ecoregions of Latin America and the Caribbean. Washington: He World Bank and The World Wildlife Fund. 139p.

EITEN, G., 1972. The Cerrado vegetation of Brazil. The Botanical Review, vol. 38, no. 2, p. 201-341.

-, 1994. Vegetação do Cerrado. In Cerrado: caracterização, ocupação e perspectivas. (M.N. Pinto, org.). p. 17-73. Editora da Universidade de Brasília, UnB/SEMATEC, Brasília, DF.

EMMONS, LH. and FEER, F. 1997. Neotropical Rainforest Mammals. A Field Guide. Second Edition. Chicago and London: University of Chicago Press. 307p.

FAGUNDES, V., CHRISTOFF, AU. and YONENAGAYASSUDA, Y., 1998. Extraordinary chromosomal polymorphism with 28 different karyotypes in the neotropical species Akodon cursor (Muridae, Sigmodontinae), one of the smallest number in rodents $(2 \mathrm{n}=16,15$ and 14). Hereditas, vol. 129, p. 263-274.

FAGUNDES, V. and YONENAGA-YASSUDA, Y., 1998. Evolutionary conservation of whole homeologous chromosome arms in the akodont rodents Bolomys and Akodon (Muridae, Sigmodontinae): maintenance of interstitial telomeric segments (IBTs) in recent of centric fusion. Chromosome Research, vol. 6, no. 8, p. 643-648.

FONSECA, GAB., HERRMANN, G., LEITE, YLR., MITTERMEIER, RA., RYLANDS, AB. and PATTON, JL., 1996. Lista anotada dos mamíferos do Brasil. Occasional Papers in Conservation Biology, vol. 4, p. 1-38.

FORD, CE. and HAMERTON, JL, 1956. A colchicine hypotonic citrate squash sequence for mammalian chromosome. Stain Technical, vol. 31, p. 247-251.

GEISE, L., 1995. Os roedores Sigmodontinae (Rodentia, Muridae) do Estado do Rio de Janeiro. Sistemática, citogenética, distribuição e variação geográfica. Departamento de Genética, IB, UFRJ. Tese de Doutorado, 388p.

GEISE, L., CANAVEZ, FC. and SEUÁNEZ, HN., 1998. Comparative karyology in Akodon (Rodentia, Sigmodontinae) from Southeastern Brazil. Journal of Heredity, Cary, vol. 89, p. $158-163$.

GEISE, L., SMITH, MF. and PATTON, JL., 2001. Diversification in the genus Akodon (Rodentia, Sigmodontinae) in Southeastern South America: Mitochondrial DNA sequence Analysis. Journal of Mammalogy, vol. 82, no. 1, p. 92-101.

GONÇALVES, PR., ALMEIDA, FC. and BONVICINO, CR., 2005. A new species of Wiedomys (Rodentia: Sigmodontinae) from Brazilian Cerrado. Mammalian Biology, vol. 70, no. 1, p. $46-60$.

KASAHARA, S. and YONENAGA-YASSUDA, Y., 1983. Sexchromosome variability in Zygodontomys lasiurus (Rodentia, Cricetidae). Cytologia, vol. 48, p. 569-576.

LANGE, RB. and JABLONSKI, EF. (eds.), 1998. Mammalia do Estado do Paraná - Marsupialia. Estudos de Biologia, Curitiba: Sociedade Paranaense de Cultura - Editora Universitária Champagnat. vol. 43, 224p.

LANGGUTH, A. and BONVICINO, CR., 2002. The Oryzomys subflavus species group, with description of two new species (Rodentia, Muridae, Sigmodontinae). Arquivos do Museu Nacional, vol. 60, no. 4, p. 285-294.

LEAL-MESQUITA, ER., FAGUNDES, V., YONENAGAYASSUDA, Y. and ROCHA, PLBD., 1993. Comparative cytogenetic studies of two karyomorphs of Thrichomys apereoides (Rodentia, Echimyidae). Revista Brasileira de Genética, vol. 16, no. 3, p. 639-651.

MAIA, V. and LANGGUTH, A., 1981. New karyotypes of Brazilian Akodont rodents with notes on taxonomy. Zeitschrift fur Säugetierkunde, vol. 46, no. 4, p. 241-249.

-, 1987. Chromosomes of the Brazilian cricetid rodent Wiedomys pyrrhorhinos (Wied, 1821). Revista Brasileira de Genética, vol. 10, no. 2, p. 229-233.

MUSTRANGI, MA. and PATTON, JL., 1997. Phylogeography and systematics of the slender mouse opossum Marmosops (Marsupialia, Didelphidae). Zoology, vol. 130, p. 1-86.

OLDS, N. and ANDERSON, S., 1987. Notes on Bolivian Mammals 2. Taxonomy and Distribution of rice rats of genus Oligoryzomys. In PATTERSON, BD. and TIMM, RM. (eds). Studies in Neotropical mammalogy: essays in hornor of Philip Hershkovitz. Fieldiana Zoology, new series, vol. 39, p. 261281.

OLIVEIRA-FILHO, AT. and RATTER, JA., 2002. Vegetation physiognomies and woody flora of the Cerrado biome. In OLIVEIRA, PS. and MARQUIS, RJ. eds. The Cerrados of Brazil. Columbia University Press, New York, p. 91-120.

PARESQUE, R., SOUZA, WP. de, MENDES, SL. and FAGUNDES, V., 2004. Composição cariotípica da fauna de roedores e marsupiais de duas áreas de Mata Atlântica do Espírito Santo, Brasil. Boletim do Museu de Biologia Mello Leitão (Nova Série), vol. 17, no. 5, p. 5-33.

PARRINI, R., RAPOSO, MA., PACHECO, JF., CARVALHÃES, AMP., MELO-JUNIOR, TA., FONSECA, SM. and MINNS, JC., 1999. Birds of the Chapada Diamantina, Bahia, Brazil. Cotinga, vol. II, p. 86-95.

PATTON, JL. and SHERWOOD, SW., 1983. Chromosome evolution and speciation in rodents. Annual Review of Ecology and Systematics, vol. 14, p. 139-159.

REIG, OA., 1989. Karyotypic repatterning as one triggering factor in cases of explosive speciation. p. 246-289. In FONDERVILA, A., ed. Evolutionary Biology of Transient Unstable Populations. Springer-Verlag Berlin Heidelberg, Berlin.

REIG, OA., GARDNER, AL., BIANCHI, NO. and PATTON, JL., 1977. The chromosomes of the Didelphidae (Marsupialia) and their evolutionary significance. Biological Journal of the Linnean Society, vol. 9, p. 191-216. 
RENS, W., O'BRIEN, PCM., YANG, F., SOLANKY, N., PERELMAN, P., GRAPHODATSKY, AS., FERGUSON, M. WJ., SVARTMAN, M., LEO, AAD., GRAVES, JAM. and FERGUSON-SMITH, MA., 2001. Karyotype relationships between distantly related marsupials from South America and Australia. Chromosome Research, vol. 9, p. 301-308.

RIEGER, TT., LANGGUTH, A. and WEIMER, A., 1995. Allozymic characterization and evolutionary relationships in the Brazilian Akodon cursor species group (Rodentia - Cricetidae). Biochemical Genetics, vol. 33, no. 9, p. 283-295.

SILVA, MJJ. and YONENAGA-YASSUDA, Y., 1997. New karyotypes of two relates species of Oligoryzomys genus (Cricetidae, Rodentia) involving centric fusion with loss of NORs and distribution of telomeric (TTAGG)n sequences. Hereditas, vol. 127, p. 217-229.

-, 1998. Karyotype and chromosomal polymorphism of an undescribed Akodon from Central Brazil, a species with the lowest known diploid chromosome number in rodents. Cytogenetics and Cell Genetics, vol. 81, p. 46-50.

-, 1999. Autosomal and sex chromosomal polymorphisms with multiple rearrangements and a new karyotype in the genus Rhipidomys (Sigmodontinae, Rodentia). Hereditas, vol. 131, p. 211-220.

SOUZA, ALG., 2005. Diversidade de espécies, variação cariotípica e distribuição dos roedores da Chapada Diamantina, Bahia. (Dissertação de Mestrado) - Museu Nacional, UFRJ, $150 \mathrm{p}$.

SOUZA, MJ., MAIA, V. and dos SANTOS, JF., 1990. Nucleolar Organizer Regions, G-and C-Bands in some Brazilian species of Didelphidae. Revista Brasileira de Genética., vol. 13, no. 4, p. $767-775$.

SVARTMAN, M. and ALMEIDA, EJCD., 1992a. The karyotype pf Oryzomys capito laticeps (Cricetidae, Rodentia) from central Brazil. Revista Brasileira de Genética, vol. 15, no. 4 , p. $963-972$.

-, 1992b. The karyotypic analysis of two Calomys species (Rodentia, Cricetidae) from Central Brazil. Caryologia, vol. 45, p. $35-42$.

-, 1993a. Pericentric inversion and X chromosome polymorphism in Rhipidomys sp. (Cricetidae, Rodentia) from Brazil. Caryologia, vol. 46, no. 2-3, p. 219-225.
-, 1993b, Robertsonian fusion and X chromosome polymorphisn in Zygodontomys (= Bolomys) lasiurus (Cricetidae, Rodentia) from Central Brazil. Revista Brasileira de Genética, vol. 16, no. 1 , p. $225-235$.

SVARTMAN, M. and VIANNA-MORGANTE, AM., 1998. Karyotype evolution of marsupials: from higher to lower diploid numbers. Cytogenetics and Cell Genetics, vol. 82, p. 263-266.

TRIBE, CJ., 1996. The Neotropical rodent genus Rhipidomys (Cricetidae: Sigmodontinae) - a taxonomic revision. University College London, Doctor of Philosophy Thesis, 316p.

VAUGHAN, TA., 1978. Mammalogy, $2^{\text {nd }}$ ed., Philadelphia, W.B. Saunders Company, 522p.

WEKSLER, M., 1996. Revisão sistemática do grupo de espécies nitidus do gênero Oryzomys (Rodentia: Sigmodontinae). Museu Nacional, UFRJ. Dissertação de Mestrado, 210p.

WEKSLER, M. and BONVICINO, CR., 2005. Taxonomy of pigmy rice rats genus Oligoryzomys Bangs, 1900 (Rodentia, Sigmodontinae) of the Brazilian Cerrado, with description of two new species. Arquivos do Museu Nacional, Rio de Janeiro, vol. 63, no. 1, p. 113-130.

WEKSLER, M., PERCEQUILLO, AR. \& VOSS, R., 2006. Tem New Genera of Oryzomyine Rodents (Cricetidae: Sigmodontinae). American Museum Novitates, vol. 3537, p. 1-29

WILSON, DE. and REEDER, DA. eds., 2005. Mammal species of the World. A taxonomic and geographic reference. $3^{\text {rd }}$ Edition. The John Hopkins University Press. Baltimore, 2141p.

YONENAGA, Y., FROTA-PESSOA, O., KASAHARA, S. and CARDOSO de ALMEIDA, EJ., 1976. Cytogenetic studies on Brazilian rodents. Ciência e Cultura, vol. 28, no. 2, p. 202-221.

YONENAGA-YASSUDA, Y., KASAHARA, S., SOUZA, M. J. and L'ABBATE, M., 1982. Constitutive heterochromatin, Gbands and nucleolus-organizer in four species of Didelphidae (Marsupialia). Genetica, vol. 58, p. 71-77.

YONENAGA, Y., 1975. Karyotypes and chromosome polymorphism in Brazilian Rodents. Caryologia, vol. 28, no. 3, p. 269-286.

ZANCHIN, NIT., 1988. Estudos cromossômicos em Oryzominos e Equimídeos da Mata Atlântica. Tese de doutorado - UFRGS. $161 \mathrm{p}$. 


\section{Appendix}

Specimens karyotyped during this study. * indicates those which had variation in their diploid number (2n), and $* *$ indicates those which had variation in number of autosome arms (NA). Acronyms for institution is CD to field numbers from MZUSP (Museu de Zoologia da Universidade de São Paulo) and the prefix LG correspond to field numbers of the collector group of L. Geise.

Marmosops incanus - Bahia State: Lençóis, Remanso (12 $36^{\prime} \mathrm{S}$ and $41^{\circ} 21^{\prime} \mathrm{W}, 452 \mathrm{~m}$ ) (Female: CD009, Males: CD011, 067).

Gracilinanus microtarsus - Bahia State: Mucugê, Mata Zé Leandro - Projeto Sempre Viva (13 ${ }^{\circ} 00^{\prime} \mathrm{S}$ and $41^{\circ} 20^{\prime} \mathrm{W}, 980 \mathrm{~m}$ ) (Female: LG409).

Monodelphis domestica - Bahia State: Lençóis, Remanso (12 $36^{\prime} \mathrm{S}$ and $\left.41^{\circ} 21^{\prime} \mathrm{W}, 515 \mathrm{~m}\right)$ (Female: CD060), Mucugê, Pousada Pé de Serra (13 ${ }^{\circ} 00^{\prime} \mathrm{S}$ and $41^{\circ} 22$ ' W, 1022 m) (Male: LG407).

Akodon aff. cursor - Bahia State: Lençóis, Remanso $\left(12^{\circ} 34^{\prime} \mathrm{S}\right.$ and $41^{\circ} 21^{\prime} \mathrm{W}$ to $12^{\circ} 36^{\prime} \mathrm{S}$ and $41^{\circ} 5^{\prime} \mathrm{W}$, 452 to $512 \mathrm{~m}$ ) (Females: CD005, 027, 062, 066, 095, $102 *-104,110,124$, Males: CD001, 025, 030, 157, 164), Morro Torre TeleBahia $\left(12^{\circ} 32^{\prime} \mathrm{S}\right.$ and $41^{\circ} 24^{\prime} \mathrm{W}$ to $12^{\circ}$ $33^{\prime} \mathrm{S}$ and $41^{\circ} 23^{\prime} \mathrm{W}, 540$ to $620 \mathrm{~m}$ ) (Females: CD141, 143*, 242, Males: CD137, 167, 178, 219).

Necromys lasiurus - Bahia State: Lençóis, Remanso (12 $36^{\prime} \mathrm{S}$ and $41^{\circ} 21^{\prime} \mathrm{W}, 475$ to $509 \mathrm{~m}$ ) (Female: CD101, Males: CD021, 065), Morro Torre TeleBahia (12 $32^{\prime} \mathrm{S}$ $41^{\circ} 23^{\prime} \mathrm{W}$ to $12^{\circ} 33^{\prime} \mathrm{S}$ and $41^{\circ} 23^{\prime} \mathrm{W}, 585$ to $618 \mathrm{~m}$ ) (Female: CD238, Male: CD196), Itaetê, Rio Saminas ( $13^{\circ} 11^{\prime} \mathrm{S}$ and $41^{\circ} 10^{\prime} \mathrm{W}, 837$ to $844 \mathrm{~m}$ ) (Females: LG222, 226), Mucugê, Rio Cumbuca, PARNA Chapada Diamantina $\left(13^{\circ} 2^{\prime} \mathrm{S}\right.$ and $41^{\circ} 20^{\prime} \mathrm{W}$ to $13^{\circ} 2^{\prime} \mathrm{S}$ and 41 ${ }^{\circ} 21^{\prime} \mathrm{W}, 988$ to $1002 \mathrm{~m}$ ) (Males: LG322, 367, 371, 377), Pousada Pé de Serra ( $13^{\circ} 00^{\prime} \mathrm{S}$ and $41^{\circ} 22^{\prime} \mathrm{W}$, $1000 \mathrm{~m})$ (Male: LG406).

Cerradomys sp. - Bahia State: Lençóis, Remanso $\left(12^{\circ} 34^{\prime} \mathrm{S}\right.$ and $41^{\circ} 24^{\prime} \mathrm{W}$ to $12^{\circ} 36^{\prime} \mathrm{S}$ and $41^{\circ} 21^{\prime} \mathrm{W}, 444$ to $509 \mathrm{~m}$ ) (Females: CD002-004**, 023, 028**, 029**, 064, 112, 125, 126**, 165, Males: CD073, 076, 120), Morro Torre TeleBahia $\left(12^{\circ} 32^{\prime} \mathrm{S}\right.$ and $41^{\circ} 23^{\prime} \mathrm{W}$ to $12^{\circ}$ $33^{\prime} \mathrm{S}$ and $41^{\circ} 23^{\prime} \mathrm{W}, 530$ to $626 \mathrm{~m}$ ) (Females: CD132, $134 * *, 135,150,168,171,173,180,186,195,198$, 206**, 243, Males: CD133, 138, 140, 149, 151, 152**,
$169,170,181,187,199,200 *, 204,217,240,241)$, Itaetê, Rio Saminas $\left(13^{\circ} 9^{\prime} \mathrm{S}\right.$ and $41^{\circ} 10^{\prime} \mathrm{W}$ to $13^{\circ} 9^{\prime} 56,3 \mathrm{~S}$ and $41^{\circ} 11^{\prime} \mathrm{W}, 813$ to $845 \mathrm{~m}$ ) (female: LG223, Males: LG211, 213), Mucugê, Rio Cumbuca, PARNA Chapada Diamantina $\left(13^{\circ} 2^{\prime} \mathrm{S}\right.$ and $41^{\circ} 20^{\prime} \mathrm{W}$ to $13^{\circ} 3^{\prime} \mathrm{S}$ and $41^{\circ}$ 20' W, 983 to $1043 \mathrm{~m}$ ) (Females: LG318, 325, 339, 340, 341, 350, 353-355, 376, 381, 383, Males: LG335, 338, 348, 372, 380, 382), Mata Zé Leandro - Projeto Sempre Viva (13 $00^{\circ} \mathrm{S}$ and $41^{\circ} 20^{\prime} \mathrm{W}, 989 \mathrm{~m}$ ) (Male: LG404), Estação de tratamento de água de Mucugê - PARNA Chapada Diamantina ( $12^{\circ} 59^{\prime} \mathrm{S}$ and $41^{\circ} 23^{\prime} \mathrm{W}, 1008 \mathrm{~m}$ ) (Male: LG403).

Oligoryzomys fornesi - Bahia State: Lençóis, Remanso $\left(12^{\circ} 34^{\prime} \mathrm{S}\right.$ and $\left.41^{\circ} 21^{\prime} \mathrm{W}\right)$ (Males: CD114, $156,161,162,203)$.

Oligoryzomys nigripes - State: Lençóis, Remanso $\left(12^{\circ} 34^{\prime} \mathrm{S}\right.$ and $\left.41^{\circ} 21^{\prime} \mathrm{W}\right)$ (Male: CD 158), Itaetê, Rio Saminas $\left(13^{\circ} 10^{\prime} \mathrm{S}\right.$ and $41^{\circ} 10^{\prime} \mathrm{W}, 813$ and $\left.853 \mathrm{~m}\right)$ (Females: LG212, 224).

Oligoryzomys rupestris - Bahia State: Itaetê, Rio Saminas $\left(13^{\circ} 10^{\prime} \mathrm{S}\right.$ and $41^{\circ} 10^{\prime} \mathrm{W}, 13^{\circ} 11^{\prime} \mathrm{S}$ and $41^{\circ} 10^{\prime} \mathrm{W}, 845$ and $877 \mathrm{~m}$ ) (Males: LG214, 228).

Calomys expulsus - Bahia State: Itaetê, Rio Saminas $\left(13^{\circ} 09^{\prime} \mathrm{S}\right.$ and $41^{\circ} 10^{\prime} \mathrm{W}, 13^{\circ} 11^{\prime} \mathrm{S}$ and $41^{\circ} 10^{\prime} \mathrm{W}, 822$ and $874 \mathrm{~m}$ ) (Males: LG221, 227), Mucugê, Estação de tratamento de água de Mucugê - PARNA Chapada Diamantina ( $12^{\circ} 59^{\prime} \mathrm{S}$ and $41^{\circ} 23^{\prime} \mathrm{W}, 983 \mathrm{~m}$ ) (Female: LG408, Male: LG405), Rio Cumbuca, PARNA Chapada Diamantina $\left(13^{\circ} 2^{\prime} \mathrm{S}\right.$ and $41^{\circ} 21^{\prime} \mathrm{W}$ to $13^{\circ} 3^{\prime} \mathrm{S}$ and $41^{\circ} 20^{\prime} \mathrm{W}, 989$ to $1000 \mathrm{~m}$ ) (Males: LG323, 347).

Rhipidomys macrurus - Bahia State: Lençóis, Remanso $\left(12^{\circ} 36^{\prime} \mathrm{S}\right.$ and $41^{\circ} 21^{\prime} \mathrm{W}, 450 \mathrm{~m}$ ) (Male: CD111).

Wiedomys pyrrhorhinus - Bahia State: Itaetê, Rio Saminas $\left(13^{\circ} 09^{\prime} \mathrm{S}\right.$ and $\left.41^{\circ} 10^{\prime} \mathrm{W}, 813 \mathrm{~m}\right)$ (Male: LG215).

Thrichomys inermis - Bahia State: Lençóis, Remanso (12 $36^{\prime} \mathrm{S}$ and $41^{\circ} 21^{\prime} \mathrm{W}, 505 \mathrm{~m}$ ) (Male: CD007), Palmeiras, Foz do Córrego do Brejão (12 ${ }^{\circ} 25^{\prime}$ $\mathrm{S}$ and $41^{\circ} 25^{\prime} \mathrm{W}, 532$ to $842 \mathrm{~m}$ ) (Females: LG249, 276, 278, 283, 285, 286, Males: LG250-252, 274, 275, 282), Mucugê, Rio Cumbuca, PARNA Chapada Diamantina $\left(13^{\circ} 2^{\prime} \mathrm{S}\right.$ and $41^{\circ} 20^{\prime} \mathrm{W}$ to $13^{\circ} 3^{\prime} \mathrm{S}$ and $41^{\circ} 20^{\prime} \mathrm{W}, 987$ to 1019 m) (Females: LG324, 333, 336, 342, 343, Males: LG332, 345, 349). 